Alambique. Revista académica de

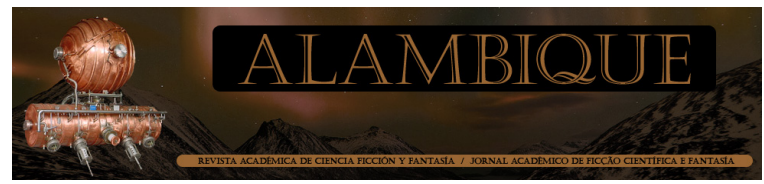

ciencia ficción y fantasía / Jornal acadêmico de ficção científica e fantasía

Volume 4

Issue 2 Manuel de Pedrolo's "Typescript

of the Second Origin"

Article 5

\title{
"Typescript of the Second Origin" and Current YA Dystopian and Post-Apocalypse Fiction in English: Prefiguring the Female Hero
}

Isabel Santaularia

University of Lleida, isantaularia@dal.udl.cat

Follow this and additional works at: https://digitalcommons.usf.edu/alambique

Part of the Feminist, Gender, and Sexuality Studies Commons

\section{Recommended Citation}

Santaularia, Isabel (2017) "'Typescript of the Second Origin" and Current YA Dystopian and Post-Apocalypse Fiction in English: Prefiguring the Female Hero," Alambique. Revista académica de ciencia ficción y fantasía / Jornal acadêmico de ficção científica e fantasía: Vol. 4 : Iss. 2 , Article 5.

http://dx.doi.org/10.5038/2167-6577.4.2.5

Available at: https://digitalcommons.usf.edu/alambique/vol4/iss2/5

Authors retain copyright of their material under a Creative Commons Attribution-Noncommercial 4.0 License. 


\section{(YA) Dystopia/Post-Apocalypse Narratives: Between Despair and Hope}

Dystopia and post-apocalypse narratives are two different subgenres of science fiction. While the former concentrates on non-existent societies subjected to totalitarian practices that oppress individuals and deprive them of their individuality and freedom, the latter features scenarios in which the population of the Earth has been decimated to the verge of extinction after a cataclysmic event of global proportions. Apart from their futuristic settings, what these two subgenres have in common is that they both depict situations that are presented as considerably worse than our own and, as a result, they explore what the future could look like if the socio-political structures that regulate our lives were either destroyed or replaced by tyrannical regimes.

Consequently, dystopia and post-apocalypse narratives have a great "capacity to frighten and warn" (Hintz, Basu and Broad 1) but they also force readers/audiences to reflect on serious global concerns that are grafted onto a dystopian or post-apocalyptic setting, such as eco-deterioration and environmental degradation, the dismantling of individual rights or the limits of individuality and freedom. They are works that "emanate from a critique of postmodern, advanced technological societies gone awry" (Zipes xi); therefore, they sensitize us to the ills, flaws and contradictions that afflict our contemporary world and that can lead to rigid or repressive regimes, even the destruction of the planet, if we do not find ways to change our unsustainable lifestyles or imagine alternative social, political or economic systems. In spite of their grim intimations about the world we are to inherit, however, dystopia and post-apocalyptic narratives also present what Raffaela Baccolini calls "a horizon of hope" (521), a space for "self-conscious speculation" (Hintz and Ostry 4) and "fruitful bewilderment" (Jameson 11) in which we can learn from fictional futures in order to make changes in the present and create a different, more humane world. Thus, dystopia and post-apocalyptic narratives do record our worst nightmares but also our "aspirations toward ideality or amelioration" (Hintz and Ostry 2), which the protagonists dramatize as they challenge malfunctioning social formations or try to survive in a world that has been radically transformed.

Given the ultimately aspirational nature of both dystopia and postapocalypse narratives, indeed of speculative or science fiction in general, these subgenres have the potential to envision new worlds where traditional gender roles no longer apply and can, therefore, be used to challenge stereotypes in the representation of women and their bodies. In fact, as Miranda A. GreenBarteet argues, the choice of a dystopian/post-apocalyptic setting is not coincidental in a number of texts with female protagonists. As she explains, "the circumstances of their (...) worlds [enable these women] to be strong, active [characters] who willingly challenge authority and even confront injustice when they feel compelled to do so. These protagonists think little of the gendered stereotypes that limit their real-life counterparts on a daily basis" (35). Precisely because in dystopian/post-apocalyptic settings "norms have 
been significantly altered by a variety of societal collapses," these texts can interrogate gender stereotypes since "the breakdown in social structures (...) allows for previously disenfranchised characters to gain power and influence based on their special skills or revolutionary leadership qualities" (DeanRuzicka 53-54). Not surprisingly, feminist science fiction writers, especially since the 1960s and 1970s that saw the emergence and development of the Women's Movement, embraced the genre to advance their own political agendas providing "description[s] of social injustices displaced in time and/or place from the readers' own society" but "clearly recognizable as a critique of that society" (Cranny-Francis 9). Authors such as Katherine MacLean, Zenna Henderson, André Norton, Josephine Saxton, Suzy McKee Charnas, Chelsea Quinn Yarbro, Ursula K. Le Guin, Joanna Russ or Margaret Atwood, to mention only some well-known names, used the "estrangement of the everyday world of experimental reality [in science fiction to] present women in new roles, liberated from the sexism endemic to their society even in it its more emancipated state" (Cranny-Francis 42).

Dystopian and post-apocalyptic settings have also become staple fare in an array of YA texts that concentrate on the protagonists' struggles to fight apparently utopian societies which are nonetheless controlled by totalitarian forces; to undermine openly despotic systems; or to survive apocalypse after alien attacks, lethal plagues or natural cataclysms. YA is a marketing label that developed during the $20^{\text {th }}$ century to make reference to texts addressed to preadolescent and teenage readers. As Day, Green-Barteet and Montz explain (67), after the success of series like the Nancy Drew and the Hardy Boys mysteries in the 1930s, in the 1950s and 1960s YA writers turned to grittier realistic fiction that explored the concerns of adolescents, a trend that has continued well into the late 1990 s and early $21^{\text {st }}$ century. Authors such as Laurie Holse Anderson, David Levithan, Meg Rosoff and John Green, for example, have written about teenage protagonists who "confront the challenges of friendship, romance and maturation against a backdrop of fears about terrorism, war, and the dangers of technology" (Day, Green-Barteet and Montz 6).

After the popularity of J.K. Rowling's Harry Potter saga (1997-2007) and the success of the television series Buffy the Vampire Slayer (1997-2003) and Stephanie Meyer's Twilight novels (2005-2008), though, YA produced in the last few years has moved away from the realism that had characterized the texts produced for teenage readers before, and wizards, witches, vampires and werewolves have become popular protagonists. The appeal of fantasy among young readers has also led to the inclusion of fantastic dystopian and postapocalyptic settings in texts that present teenage protagonists facing frightening futures. At the moment, in fact, dystopian and post-apocalyptic YA is extremely popular, with children "diving deeper into the dystopian well, finding a sense of pleasure in texts that display an increasingly gloomy vision of the world" (Hintz, Basu and Broad 2). The success of dystopian and postapocalypse YA is not accidental. Apart from being texts that invite young 
readers to explore social organizations critically and to question their own society, adolescents find much to enjoy in devastated or altered futures where teenage protagonists are given the opportunity, even encouraged, to challenge adult authority, to rebel against what they perceive as wrong, and to uphold a power and autonomy that adolescents feel they lack in their everyday lives. In these texts, teenagers who are angry, disillusioned, lonely or ostracized in their lives are, therefore, given what Hints, Basu and Broad call an everlasting "snow day" or "an island where misfit toys can shine" (6), that is, a place of freedom and opportunity where the powerless can gain control of their lives, challenge existing hierarchies and become independent and powerful.

The potential of dystopian and post-apocalyptic settings to grant power to the disenfranchised has been used in YA texts to redefine girlhood. As Beth Younger argues in Learning Curves: Body Image and Female Sexuality in Young Adult Literature, much of what young women know about gender, the body and sexuality they learn from their peers, but also from the texts they watch or they read. Consequently, YA narratives are sources of information that can inspire young girls to challenge definitions of femininity that associate girlhood with sweetness, passivity and vulnerability. Indeed, dystopian and post-apocalyptic YA narratives furnish readers with inspiring girl protagonists that contradict "the perception that girls are too young or too powerless to question the limitations placed upon them, much less to rebel and, in turn, fuel larger rebellion" (Day, Green-Barteet and Montz 4). Consequently, the teenage girl protagonists of popular trilogies like Suzanne Collins' Hunger Games-The Hunger Games (2008), Catching Fire (2009) and Mockingjay (2010) - , Veronica Roth's Divergent-Divergent (2011), Insurgent (2012) and Allegiant (2013)—, or Moira Young's Dustlands Blood Red Road (2011), Rebel Heart (2012) and Raging Star (2014)-, Katniss, Tris and Saba respectively, are "as close as contemporary popular culture gets to a representation of young feminism" (Currie, Kelly and Pomerantz 46). As the malfunctioning settings they find themselves in force these young girls to take on responsibilities and move forward towards something better, they disentangle themselves from familial bonds and the limitations of home, and they become agents of change instead of passive bystanders. As a result, they "help readers to reimagine the world, and could potentially give rise to a future where the inequalities seen today have been reconfigured in sizeable ways" (Dean-Ruzicka 72).

This portrayal of tough and powerful femininity is not new and can be regarded as part of a tradition produced for young audiences that spans more than a century. It encompasses characters that range from fictionalizations of real historical figures such as Calamity Jane and Annie Oakley in dime westerns in the 1800s; or fictional female detectives such as Nancy Drew in mystery novels and warriors such as Red Sonya and Sheena in comic books in the 1930s; to more contemporary heroines in TV shows, such as The Bionic Woman (1976-1978), Charlie's Angels (1976-1988), Xena: Warrior Princess (1995-2001), Buffy the Vampire Slayer, Dark Angel (2000-2002) or Veronica 
Mars (2004-2007). The proliferation of tough female protagonists, with Katniss, Tris and Saba as three of the most significant incorporations in the last decade, at least in the genres of dystopia and post-apocalypse narratives for young adults, ${ }^{1}$ demonstrates that popular fiction has responded to "women's desires for tough heroic identities" (Crosby 154) by offering representations of women which challenge "the male monopoly on power and aggression" (Innes 5). This, in turn, can have broad ramifications for how gender is constructed in the future, especially if we take into account the popularity of YA texts that "reject cultural constraints and reimagine futures for young women in ways that resist and reject traditional and regressive ideas of femininity, sexuality and body image" (Younger xiii).

Whether these fictional representations of powerful (teenage) femininity have the potential to lead to actual changes in society, though, is something that needs to be considered in greater detail, especially if we take into account that in our western societies gender inequality is still prevalent and the construction of a more egalitarian world seems to fall into the category of '(perpetual) work in progress'. Also, and more significantly for my arguments in this article, popular narratives in general fall short of advancing a fully progressive discourse, which is often stalled as the narratives develop and heroines are systematically made to conform to traditional forms of femininity, a tendency that feminist critics of popular fiction have examined and exposed in essays such as Imelda Whelehan's Overloaded: Popular Culture and the Future of Feminism (2000), Susan J. Douglas' The Rise of Enlightened Sexism: How Pop Culture Took Us From Girl Power to Girls Gone Wild (2010) or Rebecca Munford and Melanie Waters' Feminism and Popular Culture: Investigating the Postfeminist Mystique (2014). As these essays demonstrate, the 'horizon of hope' Baccolini writes about is precisely this, a horizon that is perpetually out of reach since it is always contemplated in the future.

\section{The Case of Alba in Manuel de Pedrolo's Typescript of the Second Origin}

The characterization of Alba, the female protagonist of Pedrolo's postapocalypse novel, throws into sharp relief the limitations of popular fiction in general and YA dystopian texts in particular to radically challenge gender roles. Published in 1974 a year before dictator Francisco Franco died, Typescript of the Second Origin is a truly exceptional text which, envisions a malleable, kind and sweet mixed-race boy, Dídac, as the future father of humankind after a devastating alien attack that leaves only a few scattered survivors on Earth. The fact that Dídac is only a 9-year-old child when the novel begins allows Alba, who outlives apocalypse with him and who is only 14 herself, to mould Dídac into the type of partner she needs to re-create the future. A representative of Catalan common-sense and very obviously influenced by the hippie movement if we take into account that her parents brought her up to eschew racial and sexual prejudices, Alba expects to found a 
new world where race is irrelevant and sex is regarded as a natural and enjoyable part of one's existence. In fact, after the shock of the destruction of the world as it was before the attack, Alba comes to see the ruins that surround them "as the materials for building a new world rather than as a sign of the old world's disintegration" (381) and herself and Dídac as "no longer those two children who had suddenly lost everything but a youth and a young woman (...) [whose] history had started the moment they had decided to be an origin rather than an end" (433). The obliteration of civilization means that "the future world could be completely different" since, after them, "people will no longer think about their skin color" (374). Also, without religion, superstitions, taboos about sex, authorities and inequalities based on class or money, Alba assumes "there cannot be any injustice" (459). All in all, they are happy the tragedy happened because it gives them the chance to become the heralds of a new, and better, civilization whereas, in the past, Alba would have been just an ordinary woman and Dídac "an ordinary wage earner, perhaps a car mechanic" (445).

The fact that Dídac dies at the end of the novel seems to preclude the reestablishment of patriarchy in the future since it is Alba who is left with the responsibility of reinventing society on her own terms. Even though Alba's loving treatment of Dídac and the process of learning she subjects him to guarantees Dídac's growth into a caring and supporting partner, Alba is very aware of the fact that she has made him "feel like a man perhaps before his time" (460) a feeling that could lead to power struggles between him and his male descendants, especially over Alba's body and those of their future daughters. This is a possibility that, though not fully developed, is intimated at the end of the novel in an episode in which Alba and Dídac talk about their hens and roosters' chick brood, which has produced "a clever little rooster which soon, you could see, would be his father's rival" (478). As Dídac observes the birds, he smiles shyly and states he "also enjoy[s] being the only rooster" (479).

In any case, if the potential of a better future exists at all, it is because of Alba's resilience, pluck, determination and practicality, as well as her humanity, which turn her into a very remarkable heroine. Unlike other apparently imperturbable and thick-skinned heroes and heroines, there is no sense that Alba is invulnerable. Apocalypse is certainly frightening. Firstly, Alba is constantly worried that the aliens that have destroyed the Earth will make a come-back to finish the work they started by killing the few survivors that remain; or that they have settled down somewhere and "from their bridgehead they [will] colonize Earth in stages" (388) so that Alba and Dídac probably live "in occupied territory" (388). Secondly, the very few survivors they find are either insane or violent, sometimes both, as is the case of the three men they encounter when Alba and Dídac sail along the Mediterranean coast looking for other people and Alba realizes their intention is clearly to kill Dídac and rape her. Finally, there is the fear of illness or injury, as when Dídac gets the measles, a disease which "in normal circumstances would not have 
been a great cause of concern" but, with only the two of them to battle it, it becomes "a tragedy for the girl" (392). Alba also experiences sadness, even despair, both for her truncated life and for those she has lost in the attack. Her frustration becomes evident in the following excerpt:

Alba just could not sleep. The piercing pain that had so far lain dormant now found her unprotected and forced her to ask herself (...) [whether it wasn't] ridiculous that she, a mere girl, wanted to go on living when everyone else was dead and she had no future?

None of her teenage expectations could be fulfilled in an empty world, in solitude. Studies, pleasure, loves ... All that had been exterminated like the houses and the people. Nothing made sense, except among them. If no accident or disease killed her, she would grow up, then grow old, without having lived at all, subjugated to the sadness of her daily struggle, with no reward for an existence that felt as heavy as her legs, her arms, her eyelids closing without finding the relief of sleep. (362, original ellipsis)

Yet, Alba does not surrender to her pain or fear and she manages to "overcome the trauma of that day now seemingly so long ago when she found the entire village destroyed, their inhabitants dead, but still had the courage to start all over again" (371). She not only protects Dídac from the horror that surrounds them by making him feel loved and secure, but she also engineers a plan of action that allows her and Dídac to survive, prosper, overcome threats and, eventually, be so happy that the nightmares she had at first experienced about the world she had lost and she desperately missed are, at the end of the narrative, triggered by the fear of being "back in the village at home in their own beds" (476).

The way Alba confronts tragedy, in any case, is also outstanding in one significant respect. The action heroines traditionally found in popular narratives, from Wonder Woman to Ripley or Sarah Connor in the Alien and Terminator sagas respectively, ${ }^{2}$ to the more recent Katniss, Tris and Saba in YA dystopia, are characterized by their powerful physiques and/or combat skills. As Jennifer Steinhauer wrote in a 2000 article in the New York Times where she reviewed that year's explosion of prime time and big screen heroines: "This year's heroines (...) are muscular and trained in the martial arts, and they have no compunctions about lapping, immolating, and kicking their way through life (...) They are restoring world order and ending bad dates with swift, punishing blows" (in Innes 1). However, as Yvonne Tasker argues, instead of refashioning femininity taking into account real-life examples of powerful females, "image makers [since the 1970s] sought to (...) [mobilize] already-existing types and conventions, images that were an established part of popular culture" (19). Thus, they either relied on an openly sexualized presentation of femininity or turned heroines into honorary men or impersonations of Jean-Claude Van Damme in drag, a trend that is still 
prevalent in contemporary YA dystopian and post-apocalypse texts. While the existence of active and strong heroines is exhilarating and may reflect the changes in the perception of women in society, these representations also "obscure the reality of a significant demographic of young women in the world today whose circumstances continue to place them at risk of slipping through the cracks of their society" (Fritz 29). Thus, these texts ultimately advance what Susan J. Douglas terms 'embedded feminism', a trend that has turned feminism, or images of women that pass as feminist, into part of our cultural landscape but which do not correspond to reality since these fictional females display "a level of command-and-control barely enjoyed by four-star generals, let alone the nation's actual female population" (Douglas 11).

Unlike these improbable heroines, Alba feels like a real girl who is believably strong. True, she does not have to confront alien armies or tyrannical oppressors since the alien attack is not followed by an invasion or the establishment of a dictatorial regime. Yet, she faces an equally despairing future with determination and applies a commonsensical approach to the challenges she encounters. Her plan of action involves gathering essentials systematically thinking about what they really need, caring about hygiene to prevent infections, finding shelter, habilitating means of transportation, exploring their surroundings and, eventually, settling down and farming animals and cultivating vegetables after a journey that makes Alba realize they are probably the last humans on Earth, at least the last humans sane enough to endure the circumstances that have befallen humankind. She does not forget to make a provision of guns and ammunition, just in case they have to hunt, but also to defend her and Dídac from threats. Alba shoots the only alien they encounter since, after all, "[this is] an enemy and its species had sufficiently proven that they were implacable" (399). The killing is done when the alien is unaware, from behind, clinically and rationally and it is, therefore, neither choreographed as an action scene nor followed by theatrical pangs of regret. What has to be done, has to be done, and Alba does not hesitate to be proactive when required or defensive when necessary - she, for example, kills a second time, using the weapon she takes from the alien to exterminate the three men that intend to get rid of Dídac and rape her. A modern-day Robinson Crusoe, Alba survives because "she had always been a fighter" (357) and, after "such a long time braving all kinds of obstacles" she and Dídac have become "patient and ingenious" (408). She furthermore understands that books are essential, not only to preserve humankind's cultural heritage but as textbooks that will allow them to learn about the areas they need to survive, especially medicine and technology. Consequently, she establishes a systematic study program for herself and Dídac that will capacitate them to use what remains after destruction to their own advantage. The ruins of civilization are, therefore, pillaged and used as means of survival, but also as building blocks to erect a new edifice altogether, one which will pay homage to the efforts of other men and women but where there will be no space for past prejudices or injustice. 
Finally, Pedrolo does not oversexualize Alba or her relationship with Dídac, at least in the way heroines and relationships are represented in contemporary popular texts where heroines are pin-ups and sex is accompanied by firework explosions and acrobatics worthy of a circus or treated as a mystery that needs to be elucidated, pondered about and puritanically postponed until the right man appears. In popular narratives, action heroines are often male fantasies that, like Lara Croft both in the videogame and in the film versions with Angelina Jolie as the protagonist, represent "extreme versions of the sexy, tough female" (Herbst 28). They are often designed to please male urges and, unlike their male counterparts, ${ }^{3}$ they are necessarily beautiful. As Rikke Schubart writes:

The female hero in a man's world has many faces. Some are provocative and subversive, some are entertaining and exploitative. Some are sexy super bitches, bad mamas, and castrating femme fatales. Others are vindictive, hurt, angry. However, whatever their archetypal nature, they are always beautiful and sexy. (38)

Alba's body, by contrast, is not conceived as a spectacle. She is lean basically because apocalypse does not allow heroines to be fat with all the exercise involved in the reconstruction of the world. She is also, we are to assume, pleasing to the eye, at least if we trust Dídac's loving gaze as he watches Alba swimming in the sea and he exclaims, "It's so beautiful! And so are you, Alba" (411). Yet, Pedrolo does not indulge in sexualized descriptions of Alba's body, which, in fact, Alba treats simply as part of what she is and which she displays naked without any sort of self-consciousness or embarrassment. In fact, when Dídac and Alba examine each other's naked bodies, at least at first, it is just to observe how skinny they have become, making Alba's breasts look bigger just because she is thinner (373). Their proximity eventually leads to their sexual awakening when Dídac becomes an adolescent at the age of twelve. Again, Pedrolo does not turn their blooming sexuality into an erotic display. Dídac begins to see Alba as a woman but their eventually romantic and sexual relationship is not a reaction to Alba's physique but the result of the loving companionship they develop and their "friendly feeling of well-being" (415). From the moment they begin to have sex, it is also treated as a normal part of life, the logical outcome of loving each other, and enjoyed with natural ease. Consequently, they continually find themselves "in each other's arms (...) stirred up by words that nobody [has] taught them and that by night —or even by day-[lead] them to love each other" (440). Alba, once pregnant, even decides they will not hide to make love when their child is born for "it is a natural act" and since they have "the chance to start all over again, [they] should do so with no hypocrisy" (471). All in all, Pedrolo does not turn their love and love-making into an opportunity to re-establish the hetero-normative standards that regulate society but as an opportunity to start something new which, we are to assume if we take into 
account Alba's liberal and strong personality, will be organized in matriarchal terms with Alba as the source of knowledge, as well as the site of power since, after all, the future of humankind depends on her capacity to reproduce and repopulate the Earth.

However, it is precisely Pedrolo's incapacity to envision a future outside reproductive heterosexuality that problematises the progressive discourse he weaves into the story. Maternity has always been a controversial issue among feminist thinkers. In The Female Eunuch (1970), Greer lamented the demise of motherhood in a society where women postpone or reject motherhood to advance in their careers since, as Ann Oakley claimed, it can still be "a valid and valuable aspect of being a woman, a source to be drawn on rather than a burden to be disposed of" (23). However, the truth remains that motherhood is still, as second-wave thinker Adrienne Rich claimed, a means of ensuring women's encapsulation within the domestic space. The future envisioned by Shulamith Firestone in which reproductive technologies would liberate women from "the tyranny of their biology" (270) has not materialized either. Even though women have more control over their bodies than ever before because of advances in contraception and fertilization that allow them to enjoy sex without worrying over pregnancy or decide to become pregnant without the need of a man, maternity is, with some exceptions, ${ }^{4}$ viewed as women's natural destiny and celebrated as their most fulfilling experience in life, which is also the view presented in Pedrolo's novel. Pedrolo per force founds the future society he envisions on pastoral, pre-industrial premises since technology has been destroyed and no alien technology is described to have remained on Earth, apart from the weapon Alba obtains from the alien she kills. Also, Alba and Dídac think they may have become the last humans alive. In this context, pregnancy becomes an imperative, in fact the only means to repopulate the Earth and Alba's main objective. Furthermore, since the future of humankind depends on Alba's fertility and capacity to give birth unproblematically given the lack of medical institutions or technologies to give a helping hand, Pedrolo naturalizes pregnancy and makes it seem as a process that has no pernicious effect whatsoever. Apart from a few hormonal changes, Alba experiences no other inconvenience-she states "she had never felt better" (466) — and gives birth "with animal ease" (469). During childbirth, she even feels "a massive, voluptuous ecstasy (...) [and] immensely happy" (469), something she had never been told about or read in any specialized volume. All in all, the creation of a New Eden depends on the New Eve being "pregnant all [her] life" (466), constantly preoccupied about the number of children she will be able to produce and focusing her life on this objective, at first, with Dídac and, after his death, with Mar, their male child. In fact, the novel ends with Alba's calculations about the children she will be able to give birth to, wishing "at the bottom of [her] heart that [Mar would be] as precocious as his father Dídac" since, "[i]f he was, [she] could still have a few children with [her] child" (484). In this way, the novel 
endorses pregnancy as women's fate and the source of female power, therefore, seems to rest, solely, on their biology.

Neither does Typescript offer evidence that Alba's progeny will manage to create a new world where old gender stereotypes and patriarchal givens no longer apply. In the epilogue of the novel, written a few thousand years after Alba's death and aptly called "Is Alba the mother of today's mankind?", the fictional editor who publishes the text ponders about its historical authenticity, assuming it is a typescript of some handwritten notebooks and collected by Alba's descendants. He explains that whereas some scholars contend it is just an ancient work of science fiction, others think it is a testament that accounts for the origins of the society in which they live, a theory that is favored by the editor taking into account some discoveries made in alien planets that suggest the alien invasion did really take place. While he gives a voice to Alba and her courageous fight for survival and states that only "somebody with Alba's mettle could be" the mother of humankind today (488, emphasis in the original), he also establishes that the text "offend[s] some taboos in our society, still quite strong today" (486). These taboos could very well refer to incestuous relationships which, if understandable in a post-apocalyptic setting, are very likely to remain taboo in demographically stable societies. However, this statement also suggests that the world Alba has given birth to is not so different from our own and that norms and forms of behavior that were operative in the past may still be prevalent in the novel's envisioned future, especially traditional gender roles. This is prefigured in the novel since Alba assumes a comforting, nurturing role while Dídac, without ever appearing as a patriarchal male, is the one who is naturally proficient in technology. Also, it is obvious that the people involved in the discussion and preservation of the typescript are male, scholar Eli Roures and antiques dealer Olguen Dalmasas. No reference is made to women being important figures in the future, which makes us assume that the 'galaxonauts' in charge of exploring the universe are also male. On the whole, Alba's main feat simply confirms women's natural fate, that of giving birth, and being a mother remains Alba's, indeed all women's, claim to fame and duty to posterity. No wonder both Dídac and Alba regard her pregnancy as an "historic event both at a personal and a collective level" (465).

\section{Other 'Future Girls' in Contemporary YA: The Case of The $5^{\text {th }}$ Wave Trilogy by Rick Yancey}

As stated throughout this essay, popular narratives have responded to the demands made elsewhere by feminists for a reformulation of traditional gender-roles and of the constructs of femininity and masculinity that served as parameters in patriarchal societies. This has opened up a space for the creation of texts that advance feminist tenets and that incorporate heroines that challenge traditional conceptions of femininity and patriarchal gender roles. Notably, in the last decade YA dystopia and post-apocalypse fiction have 
taken advantage of altered contexts to construct powerful heroines. However, there is also a tendency in popular narratives to limit the extent of the heroines' success as potential feminist icons, as can be observed in some of the most popular contemporary YA dystopia or post-apocalyptic sagas. Katniss Everdeen, the protagonist of Collins' Hunger Games trilogy may be a strong and resilient young woman who early in her life has to assume the role of breadwinner and protector of her family after her father dies and her mother abdicates her responsibilities to Katniss. She also grows up to become a leader who challenges the totalitarian regime in the novels' dystopian setting and the figurehead of the revolution against the oppressive government. However, her acts of defiance leave her exhausted in the end and she chooses a life as a wife and mother away from the new centres of power supposedly in charge of rebuilding a new and better society. The heroine of Veronica Roth's Divergent saga does not survive the fight against the oppressive system pictured in the trilogy. Saba successfully participates in the defeat of dictatorial leaders but her ferocious nature is tamed in the last volume of Moira Young's Dustlands trilogy and, after the death of her brother and sister, Saba decides to end her days as the hero's, Jack, partner. In these dystopian sagas, therefore, the role of the heroines as potential leaders is curtailed.

It is unlikely that Pedrolo could have set the pace for the creation of powerful YA heroines since the novel did not exist in translation. ${ }^{5} \mathrm{He}$ did not write for YA audiences either, though the novel is mostly consumed by young readers in Catalonia as it is a popular set text in secondary schools. In any case, with Alba, he created an interesting heroine that could have influenced the development of heroic femininity for young adults had he worked in a less marginal and more well-known culture. As explained, though, Pedrolo did not ultimately envision a female future and Alba's claim to posterity rests on her biology and capacity to repopulate the Earth. If we take into account that Pedrolo was aware of the science fiction produced in the USA and the UK, which he read, and that some feminist science fiction in the 1970s was dreaming of female futures, he did not take the cue. However, what is worrying is that more than thirty years after Pedrolo's novel was published, contemporary YA science fiction writers do not pave new roads either, at least if we focus on the most popular sagas produced in English nowadays. Instead, these sagas partake of what has been defined as our postfeminist ethos and, like many other popular narratives, do not allow for the emergence of fullyfledged heroic femininity in spite of the proliferation of female heroines in popular culture. As has been pointed out, this is the case of Collins', Roth's and Young's trilogies. It is also the case of Rick Yancey's $5^{\text {th }}$ Wave saga, which I analyze in detail and which has been singled out for comparison because the novels' opening premise is not so different from Pedrolo's and the texts use post-apocalyptic settings that open up a space for the development of female heroines. This choice allows me to substantiate my claim that, in spite of their outwardly feminist exteriors, contemporary YA dystopia and postapocalyptic narratives are not as progressive as they could be, even if they do 
incorporate capable heroines in a cultural landscape which, before the advent of feminism, was mostly inhabited by men in traditionally heroic roles.

Like Pedrolo's novel, Rick Yancey's trilogy, The $5^{\text {th }}$ Wave (2013), The Infinite Sea (2014) and The Last Star (2016), focuses on adolescents facing a desperate future after an alien invasion. Unlike Typescript, though, Yancey's aliens, referred to as 'the Others' or 'the Visitors', do not disappear after the first attack and they subject the planet to a series of destructive waves intended to annihilate the population of the Earth in five different stages. While waves one to three that the aliens unleash are straight-forward (an electromagnetic pulse, or EMP, a series of tsunamis and, finally, a lethal virus), waves four to five are not that clear for the survivors and their actual nature and purpose constitute most of the plot and are intended as a source of suspense. Eventually, readers discover that the $4^{\text {th }}$ wave are, in fact, a few humans that have been modified with alien technology, the $12^{\text {th }}$ System, which has turned them into enhanced killing machines, the Silencers. They have also been made to believe they are aliens in origin and programmed to kill what remains of humanity. The $5^{\text {th }}$ wave, on the other hand, is constituted by humans, a few thousand children targeted for their malleability and brought to different army bases supposedly to be trained to fight against the Silencers or Teds ('infecteds'). However, this is revealed to be part of the alien plot since they are actually used to unknowingly kill other humans. We also find out that the ultimate purpose of the aliens is not to destroy Earth or colonize it, since, after all, the aliens are bodiless and made of pure consciousness. Their objective is to save our planet from humans. The aliens think that all the ills that afflict our world are caused by our capacity to trust, love and cooperate with each other, which has made humans weak and will also lead, for some unexplained reason, to the destruction of our planet. Consequently, their final aim is to eliminate hope, trust and love progressively so that the few remaining humans will not confide in anyone and will kill each other. We finally discover that the aliens have relied on a few helpers or handlers that have facilitated the alien's plan, like Vosch, a commander in one of the army bases where they train the $5^{\text {th }}$-wave armies. Vosch's reward is the promise he will be taken to the mother ship and preserved as sheer consciousness. As he explains:

My consciousness will be preserved for all time abroad the mother-ship, eternally free, eternally safe from whatever may happen here. That was my price. And they agreed to pay it. (...) Because the universe has no limits, but life does. Life is rare (...) and therefore precious; it must be preserved. If [the aliens] may be said to have anything resembling human faith, it is that. All life is worthy of existence. The Earth is not the first planet they have saved. (The Last 300)

Against this context, Yancey presents a bunch of adolescent survivors who see through the aliens' intentions and fight against them. The main protagonists are Cassie Sullivan, a 16-year old girl who survives on her own 
after her parents die and her little brother, 6-year-old Sam/Nugget, is taken to an army base, Camp Haven, to be trained as a $5^{\text {th }}$-waver; a Silencer, 19-yearold Evan Walker, whose $12^{\text {th }}$ System fails when he falls in love with Cassie and decides to help and protect her; and the members of Sam's squad at Camp Haven: Ben Parish/Zombie, a 17-year-old all-American boy and quarterback who was Cassie's crush in high school; Marika Kimura/Ringer, a 17-year-old mixed-race girl with a troubled past; and the rest of their squad, a group of boys and a girl of different ages (Flinstone, Tank, Dumbo, Poundcake, Oompa and Teacup) who are killed by Silencers or sacrifice their lives to save different members of the squad. The trilogy is choral, narrated by the main protagonists: Cassie, Ben, Evan, Marika and Sam, though Cassie and Marika stand out since they are given more narrative space, and opportunities for action, than the boys.

Yancey's trilogy joins the ranks of other contemporary YA dystopias with girl protagonists who battle apocalypse and survive against all possible odds. However, Yancey's novels do not chart new territory; if anything, they take a step back and are ultimately rooted in old conventions in the presentation of gender and sex. In fact, the only progressive aspect in the presentation of the heroines has to do with their ability to assume the role of saviors of humankind and (almost) singlehandedly get rid of a few Silencers, destroy Camp Haven and blow up the alien's mother ship. Cassie and Marika are refreshing as strong females who-through a combination of initiative, courage, luck and, in Marika's case, the $12^{\text {th }}$ System she is given when Vosch sees her as one of the humans worth rescuing because of the coldness she displays as the novel develops - challenge authority and manage to survive the alien invasion. Even though, like Alba and unlike other heroines in popular narratives, Marika and Cassie are not sexualized, the novels simply celebrate the fierce and aggressive potential of girls. However, Cassie and Marika are only honorary 'Riot Grrrls' since, at the end of the day, they are not given the opportunity to change the world around them and, therefore, they lack a political edge. Also, the only sense that they are real lies in the actual 'girlishness' of their behavior, especially in the case of Cassie, which ends up confirming a superficial vision of girlhood that does not manage to subvert existing stereotypes of young femininity.

Cassie's feats of derring-do demonstrate her courageous nature. She is also funny and witty, throwing wisecracks in the purest Bruce Willis tradition as she confronts Silencers and $5^{\text {th }}$-wavers. However, her voice mostly emerges from the notebooks she keeps. These read as a personal diary where she records her obsession over boys and her body, which make her not so different from romantic heroines in chick-lit, less interested in what the future will look like than who she will spend it with. One of the first things she regrets about apocalypse is not having had the opportunity to tell Ben Parish she "loved him and wanted to have his baby more than [she] wanted to live" (The $5^{\text {th }} 62$ ). Her high-school crush is soon replaced by Evan Walker, the Silencer who first shoots her in the leg and then falls in love with her, takes her to his home, 
restores her health and then decides to help her to rescue her brother and destroy the alien's mother ship. From the moment Evan takes her under his wings, Cassie's autonomy is compromised since neither she nor, as the story develops, her friends would have survived without his intervention. In any case, after Evan is introduced in the story, Cassie's worries and concerns revolve around her feelings for Evan, especially why he has fallen in love with a girl who is so ordinary. She says: "Before the Arrival, guys like Evan Walker never looked twice at me" (The $5^{\text {th }} 173$ ). She is relieved she has been rescued by a guy who looks like Clark Kent instead of "by some fifty-year-old perv sporting a spare tire the size of a monster truck's who keeps his dead mother in the attic" (The $5^{\text {th }} 153$ ). She even states that the fact that "a very good-looking guy with a lopsided grin and large, strong hands" has become her savior is "the most unnerving thing that has happened to [her] since the Others arrived" (The $5^{\text {th }} 156$ ). Even though she resists her feelings for him, especially after she finds out he is a Silencer, she cannot but react to his "soft, chocolaty eyes," his "lean jaw", his "thick hair" and "the way it falls over his forehead when he leans over [her]" (The $\left.5^{\text {th }} 155\right)$. Neither can she disregard "his powerful shoulders (...) or his faded jeans (...) [and] the roundness of his butt inside those jeans," which make her "earlobes burn like fire" (The $5^{\text {th }}$ 163); or how she reacts to his "feathery touch" which sends "a shiver that travels down [her] spine into [her] legs, which are having a hard time keeping [her] upright" (The $5^{\text {th }} 178$ ). Eventually she gives in to her feelings but Yancey's approach to Cassie and Evan's relationship is prudish, even puritanical, giving the impression that good boys, like Evan, should not take advantage of their good looks to have sex with girls and that girls should not act upon their sexual desire. Evan and Cassie do have sex on one occasion, at least if we read between the lines and assume that, when Cassie tells Evan it is the right time, he complies, because Yancey leaves the episode when this happens in suspense (The $\left.5^{\text {th }} 102-103\right)$. By glossing over adolescent sexuality, Yancey does not consider its undersides and complications, or its many pleasures, turning sex into part of a romantic fantasy with no firm grounds on adolescents' real experiences or preoccupations about sex.

Yancey also spends a lot of narrative space with Cassie's selfconsciousness about her skinny body, flat chest, freckles, bad hair, and, after a fight with a Silencer, her crooked nose. Her imperfections do not only make her feel insecure around Evan and other boys, but also around beautiful girls. Thus, as she battles Silencers and aliens, Cassie still finds time to compare herself to beautiful Marika or Grace, a Silencer who had known Evan before the Arrival and who claims she had had sex with him, which triggers a response of jealousy. In fact, when Cassie engages Grace in combat, it seems it is her envy that motivates her and not Grace's villainy-she thinks to herself: "I am going to rip her cover-model face off. I am going to tear her pseudo-human heart from between her perfectly shaped human boobs. I am going to open her up with my fingernails" (The Infinite 164). Cassie also sees Marika as a competitor more than as a companion, firstly because Ben Parish 
seems to like her and secondly because she is described as very pretty. In the last crucial scene when both she and an enhanced Marika lead the final attack against the mother ship, her mission seems to be a secondary concern as she ponders about the things that worry her, especially: "why [Marika] has the silkiest, most beautiful hair I've ever seen, and why I don't, and why she has perfect porcelain skin, which I don't. And the nose. Good Christ (...) It's just genes with a little alien technology thrown in, big whoop" (The Last 238). In the first section of The $5^{\text {th }}$ Wave, "The Last Historian", Cassie thinks she is the last human on Earth and regards the notebooks she writes as her testament to the future. However, her notebooks turn to be an account of a young girls' insecurities in a society where an alien apocalypse has completely destroyed the planet, but has not managed to erase the perception that beauty matters in and to girls; that boys and relationships are girls' main concerns; and that girls are unable to create networks of female solidarity as they see each other as competitors. Yancey insists it is Cassie's courage that is her most relevant trait and other characters, including Marika, acknowledge her aplomb, pluck and determination. However, it is her 'girlishness' that stands out, especially if we take into account that she is not given the opportunity to grow into a mature woman in an altered new future since Cassie does not survive the ordeal. Cassie's last feat of courage is her decision to use her own body as the container of a bomb that will destroy the mother ship. Her suicide mission not only attests to the discomfort patriarchal culture feels with powerful and strong female characters, that are often returned to the domestic space, as is the case of Katniss in the Hunger Games trilogy, or eliminated altogether, like sacrificial heroines such as Xena in Xena: Warrior Princess or Tris in the Divergent trilogy. It also has other troubling ramifications. Firstly, Cassie's final sacrifice does not manage to erode her essential 'romantic heroine' status and, before she dies, she has a moment of epiphany in which she happily understands Evan really loved her for what she is, not because there were not many other girls left. And secondly, after Cassie's elimination of the aliens and her own death, Yancey does not imagine a new, less patriarchal, world with girls as leaders.

In fact, Yancey's characters, unlike Alba and Dídac, do not see apocalypse as an opportunity to build a new world but as the end of their old lives, which they nostalgically recall and aspire to re-create. Before the Arrival, the protagonists lived with their parents in peaceful suburban homes or farms, where mothers nurtured, fathers provided - not only money, but also instruction - and older children looked after their little brothers and sisters. The Arrival is, then, "the tolling of a bell, a timer clicking down to the end of normal," to "the end of Christmas trees and birthday cakes and family vacations and ten other taken-for-granted things" (The $5^{\text {th }} 275$ ). In the novels, this is the past world that needs to be preserved and reconstructed and Yancey makes sure this is the case. To that purpose, he highlights that, because of the alien's plans to remove love and trust from Earth, the world has become much worse than it was, not only because of destruction itself; or because of the 
looting, roaming gangs and killings that ensued after the attacks; but because children are denied their right to a world of "[c]rayons and coloring books. Construction paper and glue. Teddy bears and footy pajamas, swing sets and storybooks" (The Last 206). Yancey also guarantees a return to normative patriarchal families, which is the ultimate happy ending he provides at the end of the trilogy. Thus, once he has eliminated Cassie as a potential leader, Yancey completely rewrites Marika as a character. Marika, who had come across as unlikeable because of her cold and unfeeling nature, is, first of all, provided a tragic, broken-home, drunkard-father past to account for her aloofness and, as a consequence, she is turned into a more sympathetic figure. And, then, she is eliminated as a potential leader, a role which would suit her well taking into account she has been endowed with the $12^{\text {th }}$ System, so she has enhanced physical powers, and she is well-equipped with intelligence, rationality and a no-nonsense attitude to boys and relationships. However, in the third volume, she unexpectedly announces she is pregnant by a $5^{\text {th }}$-waver who looked after her while she, for a period, was Vosch's prisoner. As a result, her fate is sealed. At the end of the novel, Marika is softened, domesticated and ultimately reduced to looking after a reconstituted conventional family unit in which Ben is the provider and Marika the caretaker, nurturing her baby girl, another girl they keep with them, Megan, and Sam. Meanwhile, Evan sets off into the sunset to destroy the $5^{\text {th }}$-wave bases that remain. And just in case we are left with any doubt about what role Marika will play in the future, she promises Cassie she will look after the children, especially Sam, who she is going to "take care of ... keep him safe and make sure he bathes and brushes his teeth and trims his nails and wears clean underwear and learns to read. Teach him to be patient and to be kind and to trust everyone" (The Last 304). And the world goes back to what it was, ominously replicating itself in a cycle that involves, as an anonymous man at the beginning of The Last Star puts it: "You grow up; you go to school. Find a job. Get married. Start a family” (8).

\section{Conclusions}

On the book covers of contemporary YA post-apocalypse and dystopian narratives with female protagonists, heroines stand out, often outlined against a desolate landscape and framed as exceptional girls in extreme circumstances. Thus, these books advance a promise of female agency, independence and empowerment which, as the plots develop, actually fails to materialize. The novels pay lip service to the advances of feminism in society by catapulting girls into bleak and forbidding situations where they have the opportunity to become heroines, fight alien invasions, survive apocalypse. Yet, YA authors, both male and female, foreclose alternative possibilities for radically female futures and pre-empt the political participation of girls in the construction of a new world. As I have attempted to demonstrate, this is what happens in Yancey's trilogy, which does not even 
assume the past has to be reconfigured into alternative forms of familial organization that will give women freedom to escape their traditional domestic roles. In Yancey's novels, the nuclear family is idealized as the antithesis to dystopia and future female leaders are either dispensed with, as is Cassie's case, or made to conform to domesticity and motherhood, Marika's fate. Pedrolo's Typescript, in turn, envisages a new beginning altogether and presents a brave and commonsensical heroine on whose shoulders rests the future of humankind. However, Pedrolo's novel predicates the thrilling utopian future he dreams of on reproduction and condemns Alba to a life of pregnancies. And it is not even clear the world she will generate will be built on more egalitarian terms, at least if we take into account the epilogue of the novel, which paints a society not so different from our own. In any case, Pedrolo prefigured an interesting heroine that could have influenced the development of other 'future girls' if the novel had existed in translation and had been given enough visibility. Almost forty years after Pedrolo's Typescript and in spite of the literary baggage of feminist science fiction in English, contemporary YA writers have not managed, or dared, to develop their heroines into consistent feminist types, at least the ones considered in this article. The transformative potential of dystopian futures, all in all, is stalled in contemporary YA, exiled to the realm of possibility, a perpetual promise of a future-to-come while, in the meantime, offering retrograde conceptions of female identity. If we take into consideration that these texts constitute the reading material of young readers nowadays-Pedrolo's text is compulsory reading in some high schools in Catalonia-, their capacity to equip future generations with feminist ideas is questionable since they ultimately undermine their progressive discourses by failing to imagine worlds where women exist as leaders of their societies past their adolescence. These heroines are powerful while they are teenagers but they are not allowed to grow into dominant women, so maturity for women is ultimately associated with monogamous relationships, marriage and motherhood.

\section{Notes}

${ }^{1}$ Analyzed in books such as Innes' Action Chicks, Mainon and Ursini's The Modern Amazons or Skuller's Ink-Stained Amazons and Cinematic Warriors.

${ }^{2}$ Wonder Woman is a super hero with supernatural powers and a mythological/fantastic character. Ripley and Sarah Connor are science fiction heroes who begin their respective sagas as relatively fragile and helpless and are not trained to fight at all. However, as the sagas evolve, these two characters develop combat skills. Though Wonder Woman, Ripley and Sarah Connor belong to different genres and have different appearances (Wonder Woman is sexy and feminine whereas Ripley and Sarah Connor acquire muscled, masculine physiques to go with their combat skills) they all challenge perceptions that associate femininity with sweetness and passivity.

${ }^{3}$ Rikke Schubart writes, "It's not fair. Heroes can have broken teeth and squint like Clint Eastwood, suffer from a speech defect like Sylvester Stallone, have foreign accents like Arnold Schwarzenegger and Jean-Claude Van Damme, be old like Charles Bronson, bald like 
Kojak, wear constant I-am-very-very-pissed-off expressions like Steven Seagal, or be just plain ugly like Chuck Norris. In short, men don't have to look good to be heroes" (1).

${ }^{4}$ Orna Donath's study on women who regretted motherhood, Madres arrepentidas, generated plenty of controversy when it was published in Spain. In the book, she presents the results of her study in which she interviewed women and which demonstrates that, even though mothers may love their children, maternity is not necessarily a panacea and is often a cause of great suffering and guilt.

5 Sara Martín's translation of the novel into English has been accepted for publication by Wesleyan University Press and will be released in 2018.

\section{Works Cited}

Baccolini, Raffaela. "The Persistence of Hope in Dystopian Science Fiction." PMLA 119.3 (2004): 518-521. Print.

Cameron, James and Charles H. Eglee, creators. Dark Angel. Cameron/Eglee Productions, 2000-2002. Television series.

Collins, Suzanne. Catching Fire. New York: Scholastic, 2009. Print.

---. Mockingjay. New York: Scholastic, 2010. Print.

---. The Hunger Games. New York: Scholastic, 2008. Print.

Cranny-Francis, Anne. Feminist Fiction: Feminist Uses of Generic Fiction. London: Polity, 1990. Print.

Crosby, Sara. "The Cruelest Season: Female Heroes Snapped into Sacrificial Heroines". Action Chicks: New Images of Tough Women in Popular Culture. Sherrie A. Innes, ed. New York: Palgrave Macmillan, 2004. 153178. Print.

Currie, Dawn, Deirdre M. Kelly, and Shauna Pomerantz. Girl Power: Girls Reinventing Girlhood. New York: Peter Lang, 2009. Print.

Day, Sara K, Miranda A. Green-Barteet, and Amy L. Montz. Female Rebellion in Young Adult Dystopian Fiction. Farham, Surrey, UK: Ashgate, 2014. Print.

Dean-Ruzicka, Rachel. "Of Scrivens and Sparks: Girl Geniuses in Young Adult Dystopian Fiction." Female Rebellion in Young Adult Dystopian Fiction. Sara K. Day, Miranda A. Green-Barteet, and Amy L. Montz, eds. Farham, Surrey, UK: Ashgate, 2014. 51-74. Print.

Donath, Orna. Madres arrepentidas: Una mirada radical a la maternidad y sus falacias. Translated by Ángeles Leiva Morales. Barcelona: Penguin Random House, 2016. Print.

Douglas, Susan J. The Rise of Enlightened Sexism: How Pop Culture Took Us from Girl Power to Girls Gone Wild. London: St. Martin's Griffin, 2010. Print.

Firestone, Shulamith. The Dialectic of Sex: The Case for Feminist Revolution. New York: Bantam, 1970. Print.

Fritz, Sonya Sawyer. "Girl Power and Girl Activism in the Fiction of Suzanne Collins, Scott Westerfeld, and Moira Young." Female Rebellion in Young 
Adult Dystopian Fiction. Sara K. Day, Miranda A. Green-Barteet, and Amy L. Montz, eds. Farham, Surrey, UK: Ashgate, 2014. 17-31. Print.

Goff, Ivan and Ben Roberts, creators. Charlie's Angels. Spelling-Goldberg Productions, 1976-1988. Television series.

Green-Barteet, Miranda A. "'I'm beginning to know who I am': The Rebellious Subjectivities of Katniss Everdeen and Tris Prior." Female Rebellion in Young Adult Dystopian Fiction. Sara K. Day, Miranda A. Green-Barteet, and Amy L. Montz, eds. Farham, Surrey, UK: Ashgate, 2014. 33-49. Print.

Greer, Germaine. The Female Eunuch. New York: Flamingo Modern Classics, 1970. Print.

Herbst, Claudia. "Lara's Lethal and Loaded Mission: Transposing Reproduction and Destruction." Action Chicks: New Images of Tough Women in Popular Culture. Sherrie A. Innes, ed. New York: Palgrave Macmillan, 2004. 21-45. Print.

Hintz, Carrie, and Elaine Ostry, eds. Utopian and Dystopian Writing for Children and Young Adults. London and New York: Routledge, 2003. Print.

Hintz, Carrie, Balaka Basu, and Katherine R. Broad. Contemporary Dystopian Fiction for Young Adults: Brave New Teenagers. London: Routledge, 2015. Print.

Innes, Sherrie A., ed. Action Chicks: New Images of Tough Women in Popular Culture. New York: Palgrave Macmillan, 2004. Print.

Jameson, Frederic. "Of Islands and Trenches: Neutralization and the Production of Utopian Discourse.” Diacritics 7.2 (1977): 2-21. Print.

Johnson, Kenneth, creator. The Bionic Woman. MCA/Universal in association with Harve Bennett Productions, 1976-1978. Television series.

Mainon, Dominique, and James Ursini. The Modern Amazons: Warrior Women On-Screen. Newark, NJ: Limelight Editions, 2006. Print.

Munford, Rebecca, and Melanie Waters. Feminism and Popular Culture: Investigating the Postfeminist Mystique. London and New York: I.B. Tauris, 2014. Print.

Oakley, Ann. From Here to Maternity: Becoming a Mother. London: Penguin, 1981. Print.

Pedrolo, Manuel de. Mecanoscrit del Segon Origen/ Mecanoscrito del Segundo Origen/ Typescript of the Second Origin. Sara Martín Alegre, ed. and trans. English version; Domingo Santos, trans. Spanish version. Lleida: Diputació de Lleida/Institut d'Estudis Ilerdencs, 2016. Print.

Rich, Adrienne. Of Woman Born: Motherhood as Experience and Institution. London: Virago, 1977. Print.

Roth, Veronica. Allegiant. London: HarperCollins Children's Books, 2013. Print.

---. Divergent. London: HarperCollins Children's Books, 2011. Print.

---. Insurgent. London: HarperCollins Children's Books, 2012. Print. 
Schubart, Rikke. Super Bitches and Action Babes: The Female Hero in Popular Cinema, 1970-2006. Jefferson, NC: McFarland \& Company, 2007. Print.

Schulian, John and Robert Tapert, creators. Xena: Warrior Princess. Renaissance Pictures, 1995-2001. Television series.

Stuller, Jennifer K. Ink-Stained Amazons and Cinematic Warriors: Superwomen in Modern Mythology. London and New York: I.B. Tauris, 2010. Print.

Tasker, Yvonne. Spectacular Bodies: Gender, Genre and the Action Cinema. London and New York: Routledge, 1993. Print.

Thomas, Rob, creator. Veronica Mars. Stu Segall Productions, 2004-2007. Television series.

Whedon, Joss, creator. Buffy the Vampire Slayer. Mutant Enemy Productions, 1997-2003. Television series.

Whelehan, Imelda. Overloaded: Popular Culture and the Future of Feminism. London: The Women's Press, 2000. Print.

Yancey, Rick. The $5^{\text {th }}$ Wave. London: Penguin, 2013. Print.

---. The Infinite Sea. London: Penguin, 2014. Print.

---. The Last Star. London: Penguin, 2016. Print.

---. Blood Red Road. London: Marion Lloyd Books, 2011. Print.

---. Raging Star. London: Marion Lloyd Books, 2014. Print.

---. Rebel Heart. London: Marion Lloyd Books, 2012. Print.

---. Learning Curves: Body Image and Female Sexuality in Young Adult Literature. Lanham, Md.: The Scarecrow Press, 2009. Print.

Zipes, Jack. "Utopia, Dystopia and the Quest for Hope." Utopian and Dystopian Writing for Children and Young Adults. Carrie Hintz and Elaine Ostry, eds. London and New York: Routledge, 2003. ix-xi. Print. 